\title{
PENGATURAN PERIZINAN PENGELOLAAN TAMBANG DALAM MENDUKUNG PEMBANGUNAN BERKELANJUTAN
}

\author{
Iriantini M. J Takalapeta \\ Prodi Magister Ilmu Hukum Universitas Nusa Cendana Kupang, \\ NTT, Indonesia \\ Email: takalapetaira005@gmail.com \\ Jimmy Pello \\ Prodi Magister Ilmu Hukum Universitas Nusa Cendana Kupang, \\ NTT, Indonesia \\ Email: jimmypello28@gmail.com

\section{Saryono Yohanes} \\ Prodi Magister Ilmu Hukum Universitas Nusa Cendana Kupang, \\ NTT, Indonesia \\ Email: saryonoyohanes@gmail.com
}

\begin{abstract}
Abstrak
Pengelolaan tambang di Kabupaten Alor harus diatur sesuai dengan ketentuan peraturan perundang-undangan agar tidak mencemari lingkungan dan menimbulkan akibat hukum. Penelitian ini menggunakan metode penelitian hukum normatif. Dalam penelitian ditemukan, pertama; pemberian izin pertambangan di Kabupaten Alor pada umumnya belum berjalan sesuai dengan peraturan perundang-undangan yang berlaku sehingga mengakibatkan adanya pelanggaran terhadap izin lingkungan khususnya pada izin eksplorasi, kedua; pelaksanaan pembinaan dan pengawasan sebagai bentuk penegakan hukum dari Pemerintah Daerah dalam hal ini instansi teknis terkait kepada pengusaha tambang belum dilakukan secara efektif sehingga belum mampu membangun kesadaran hukum secara utuh. Saran yang diberikan, pertama; pemberian izin pengelolaan tambang dalam menunjang pembangunan berkelanjutan di Kabupaten Alor harus melibatkan dinas terkait untuk melakukan sosialisasi tentang hak dan kewajiban dan sanksi yang akan diberikan kepada perusahaan yang akan melakukan usaha tambang, kedua; harus dibuat Peraturan daerah khusus tentang pemberian Lingkungan Hidup.
\end{abstract}

\section{Kata Kunci: Lingkungan; Pengaturan; Tambang}

\begin{abstract}
The management of the mine in Alor Regency must be regulated in accordance with the provisions of legislation so as not to pollute the environment and cause legal consequences. This study uses normative legal research methods. In the study found, first; mining permits in Alor Regency in general have not been carried out in accordance with applicable laws and regulations resulting in violations of environmental permits, especially in exploration permits, secondly; the implementation of guidance and supervision as a form of law enforcement from the Regional Government in this case the related technical agency to the mining businessman has not been carried out effectively so that it has not been able to develop legal awareness in its entirety. Advice given, first; granting permits for mining management in supporting sustainable development in the district of Alor must involve the relevant agencies to carry out socialization of rights and obligations and sanctions to be given to companies that will conduct mining business, second; Special regional regulations regarding the provision of the Environment must be made.
\end{abstract}

Keywords: Mine; Environment; Arrangement 


\section{A. PENDAHULUAN}

Indonesia merupakan negara yang kaya akan bahan galian (Tambang). Bahan galian itu meliputi emas, perak, tembaga, minyak dan gas bumi batu bara dan lain-lain. Bahan galian itu dikuasai oleh negara. Hak menguasai oleh negara berisi wewenang untuk mengatur, mengurus dan mengawasi pengelolaan atau pengusahaan bahan galian, serta berisi pengaturan untuk mempergunakannya sebesar-besarnya bagi kemakmuran rakyat. ${ }^{1}$

Usaha pertambangan merupakan salah satu usaha yang sangat diandalkan oleh pemerintah Indonesia guna mendatangkan devisa bagi negara. Selain mendatangkan devisa usaha pertambangan ini juga membuka lapangan kerja baru yang menyedot banyak tenaga kerja. Dampak positif bagi daerah bahwa usaha pertambangan juga memberikan kontribusi yang besar bagi Pendapatan Asli Daerah. Usaha pertambangan di Indonesia tersebar di seluruh wilayah Indonesia yang bergerak dalam kegiatan eksplorasi, eksplotasi, pengelolaan/ pemurnian dan pengangkutan mineral bahan tambang. Selain dampak positif dari usaha pertambangan ini, pengelolaannya juga tidak dilakukan sesuai dengan ketentuan perundangundangan yang berlaku. Adapun dampak negatif dari usaha pertambangan yakni kerusakan lingkungan, pencemaran udara, pencemaran tanah, keringnya sumber air tanah. Hal inilah yang perlu disikapi oleh pemerintah agar usaha pertambangan ini tidak mendatangkan bencana bagi masyarakat yang berada di daerah lingkar tambang.

Pemerintah Kabupaten Alor diberi kewenangan untuk mengelola usaha pertambangan berdasarkan Undang-Undang No. 4 Tahun 2009 tentang Pertambangan Mineral dan Batubara, Peraturan Pemerintah Nomor 23 tahun 2010 yang telah diubah dengan Peraturan Pemerintah Nomor 24 Tahun 2012 tentang Pelaksanaan Kegiatan Usaha Pertambangan Mineral dan Batubara Undang-Undang No. 32 Tahun 2009 tentang Perlindungan dan Pengelolaan Lingkungan Hidup, Peraturan Menteri Lingkungan Hidup No 27 Tahun 2012, PERDA Nomor 8 Tahun 2011 tentang Pengelolaan Pertambangan Mineral dan Batubara di Provinsi Nusa Tenggara Timur, Perda Nomor 9 Tahun 2011 tentang Pengelolaan Mineral dan Batubara di Kabupaten Alor.

Provinsi Nusa Tenggara Timur kaya akan bahan galian tambang khususnya Kabupaten Alor yang memiliki banyak bahan galian tambang mineral berupa emas, tembaga, timah hitam, galena, mangan, gipsum, kaolin dan batu apung, batu hitam, batu gamping dan bahan galian lainnya semuanya terlihat dalam tabel di bawah ini.

Tabel 1. Data lokasi bahan tambang

\begin{tabular}{|c|c|c|c|c|}
\hline No & Potensi Mineral & Lokasi & Luas & Ket \\
\hline $\mathbf{I}$ & \multicolumn{4}{|l|}{ MINERAL LOGAM } \\
\hline 1 & $\begin{array}{l}\text { Emas dan Logam Dasar } \\
\text { (Tembaga \& Timah } \\
\text { hitam ) }\end{array}$ & $\begin{array}{l}\text { Desa Helerman \& Pro- } \\
\text { bur-ABAD }\end{array}$ & $1.000 \mathrm{Ha}$ & $\begin{array}{c}\text { Izin telah berkahir } \\
\text { tanggal } 10 \text { mei } \\
2015\end{array}$ \\
\hline 2 & Emas dan Barit & $\begin{array}{l}\text { Desa bukit mas \& Kelura- } \\
\text { han Kabir-Pantar }\end{array}$ & $5.000 \mathrm{Ha}$ & \\
\hline 3 & Timah hitam dan Tembaga & \begin{tabular}{|ccc} 
Desa wakapsir \& Wakapsir \\
Timur
\end{tabular} & $3.414 \mathrm{Ha}$ & \\
\hline 4 & Timah hitam dan Tembaga & $\begin{array}{l}\text { Desa Lipang pido \& Kenarim- } \\
\text { bala }\end{array}$ & $3.250 \mathrm{Ha}$ & \\
\hline 5 & Timah hitam dan Barit & $\begin{array}{l}\text { Desa Kuneman AL- } \\
\text { SEl, Desa Langkuru, } \\
\text { Langkuru Utara, Pure- } \\
\text { man }\end{array}$ & $1.220 \mathrm{Ha}$ & \\
\hline
\end{tabular}

${ }^{1}$ H. Salim. (2013).Hukum Pertambangan Indonesia. Jakarta:Raja Grafindo Persada. hlm. 1 


\section{[JATISWARA] [Vol. 34 No. 3 November 2019]}

\begin{tabular}{|c|c|c|c|c|}
\hline 6 & Timah hitam & Desa Wolwal-ABAD & $1.985 \mathrm{Ha}$ & $\begin{array}{l}\text { Izin telah berkahir } \\
\text { tanggal } 8 \text { mei } 2013\end{array}$ \\
\hline 7 & Timah hitam & $\begin{array}{l}\text { Desa Ombai batu \& Merde- } \\
\text { ka-Pantar Timur }\end{array}$ & $9.562 \mathrm{Ha}$ & \\
\hline 8 & Timah hitam dan Barit & Desa tanglapui-ALTIM & & \\
\hline 9 & Emas dan Mangan & $\begin{array}{l}\text { Desa Talwai-Lembur, Desa Ke- } \\
\text { laisi timur }\end{array}$ & $3.970 \mathrm{Ha}$ & \\
\hline 10 & Potensi pasir besi & $\begin{array}{l}\text { Desa Mausamang-ALTIM } \\
\text { Desa Elok (pantai erana) } \\
\text {-ALTIM } \\
\text { Desa Alila Timur Pantai } \\
\text { ilawei-Kabola } \\
\text { Desa batu ombai Pantar } \\
\text { Timur } \\
\text { Desa Pura barat(pantai } \\
\text { dolabang) P.Pura } \\
\text { Desa Kalondama Pantar } \\
\text { Barat }\end{array}$ & $\begin{array}{l}634 \mathrm{Ha} \\
227 \mathrm{Ha} \\
44 \mathrm{Ha} \\
46 \mathrm{Ha} \\
12 \mathrm{Ha} \\
30 \mathrm{Ha}\end{array}$ & \\
\hline II & \multicolumn{4}{|c|}{ MINERAL DAN LOGAM } \\
\hline 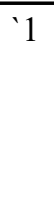 & Gypsum & $\begin{array}{l}\text { Desa leer Pantar Barat, } \\
\text { Desa Helerman-ABAD }\end{array}$ & $\begin{array}{l}1.458 \mathrm{Ha} \\
50 \mathrm{Ha}\end{array}$ & \\
\hline 2 & Kaolin & Desa Aromaba Pantar Tengah & $1.400 \mathrm{Ha}$ & \\
\hline 3 & Pasir kuarsa & $\begin{array}{l}\text { Desa Tude Pantai puntaru Pantar } \\
\text { Tengah } \\
\text { Desa Otvai-ABAL }\end{array}$ & $\begin{array}{l}1.1 \mathrm{Ha} \\
0,8 \mathrm{Ha}\end{array}$ & \\
\hline
\end{tabular}

\begin{tabular}{|l|l|l|l|l|}
\hline III & \multicolumn{4}{|l|}{ BATU DAN MINERAL BATUAN } \\
\hline 1 & Batu apung & Desa Muriabang-Pantar & $2.000 \mathrm{Ha}$ & \\
\hline 2 & Batu hitam & Desa Kuifana & $7 \mathrm{Ha}$ & \\
& & Desa Lakatuli & $7,05 \mathrm{Ha}$ & \\
& & Desa Padang alang & $5,54 \mathrm{Ha}$ & \\
\hline 3 & Pasir dan Bartu Sirtu & Desa Purnama & $18,69 \mathrm{Ha}$ & \\
& & Desa elok & $23,88 \mathrm{Ha}$ & \\
& & Desa ampera & $10 \mathrm{Ha}$ & \\
& & Desa Dulolong & $15 \mathrm{Ha}$ & \\
& & Desa Nurbenlelang & $15 \mathrm{Ha}$ & $17 \mathrm{Ha}$ \\
\hline
\end{tabular}


Sehubungan dengan pengaturan Izin Usaha Pertambangan yang telah diatur dalam UndangUndang Nomor 4 Tahun 2009 maka Pemerintah Kabupaten Alor juga telah menetapkan Izin Usaha Pertambangan yang diatur dalam Pasal 35, 36 Peraturan Daerah Nomor 9 Tahun 2011.

Usaha pertambangan mineral dan logam khusus batuan berwarna/galian c diminati oleh banyak pengusaha karena mempunyai nilai ekonomi yang tinggi. Usaha ini sebenarnya mendatangkan bencana besar bagi masyarakat yang tinggal di daerah lingkar tambang, jika para penambang tidak mengikuti peraturan perundang-undangan yang berlaku, realita kegiatan pertambangan yang dilakukan oleh para pengusaha tidak sesuai dengan apa yang diharapkan dalam ketentuan pemberian izin di mana dokumen izin tambang yang seharusnya menjadi persyaratan untuk mendapat izin tidak dilengkapi dengan dokumen izin lingkungan. Untuk lebih jelas dapat dilihat pada tabel di bawah ini yang menggambarkan ketidakpatuhan pengusaha dalam melaksanakan perizinan yang diberikan oleh pemerintah daerah.

Sesuai dengan data pada tabel 1 dilihat bahwa pelanggaran yang dilakukan oleh para pengusaha tambang, ${ }^{2}$ tidak sesuai dengan Pasal 36 ayat (1) Undang-Undang Nomor 32 Tahun 2009, sehingga terjadi kerusakan lingkungan yang dapat menyebabkan terganggunya ekosistem dan juga bisa merenggut nyawa masyarakat jika dilihat secara cermat sebenarnya ada terjadi ekspansi di wilayah pertambangan tanpa izin lingkungan, ada pengerusakan biota laut, ada penggalian batu berwarna yang berlebihan sehingga mengakibatkan abrasi dan kerusakan lingkungan sekitarnya.

Pemerintah turut berperan terhadap kerusakan lingkungan oleh karena dalam melaksanakan kewenangan pengelolaan usaha tambang seperti penerbitan izin lingkungan tidak dikaji dengan baik dan tidak cermat dalam penerapan izin bagi yang melanggar prosedur izin lingkungan. Dalam upaya percepatan pembangunan di daerah dan peningkatan taraf hidup dari masyarakat, maka pemerintah perlu untuk memfasilitasi dan mengawasi seluruh potensi alam yang terkandung di dalamnya. Kewenangan negara dalam pengelolaan pertambangan mineral dan batubara merupakan hak dan kekuasaan yang dimiliki oleh negara untuk melakukan penataan, pemanfaatan, pemulihan, pengawasan dan pengendalian terhadap kegiatan pertambangan mineral dan batubara yang diberi kewenangan untuk mengelola pertambangan mineral dan batubara adalah Pemerintah, Pemerintah Provinsi, dan Pemerintah Kabupaten/Kota. ${ }^{3}$

Kewenangan pengawasan yang dilakukan Pemerintah Kabupaten Alor sesungguhnya ditujukan kepada pihak pengusaha pertambangan, baik yang memiliki IPR (Izin Pertambangan Rakyat) maupun perusahaan yang memiliki IUP (Operasi Produksi) dari tingkat Eksplorasi hingga Operasi Produksi. Menurut Pasal 139 Undang-Undang No. 4 Tahun 2009 menegaskan bahwa Menteri, Gubernur, Bupati/Walikota sesuai kewenangannya bertanggung jawab melakukan pembinaan atas kegiatan pelaksanaan kegiatan usaha pertambangan yang dilakukan oleh pemegang IUP, IPR dan IUPK. ${ }^{4}$ Selanjutnya dalam pasal 140 Ayat ( 3 ) berbunyi: Menteri, Gubernur, Bupati/Walikota sesuai kewenangan melakukan pengawasan atas pelaksanaan kegiatan usaha pertambangan yang dilakukan oleh pemegang IUP, IPR dan IUPK. Itu berarti bahwa sesungguhnya Pemerintah Pusat telah mendelegasikan sebagian kewenangan secara penuh kepada Pemerintah Kabupaten/Walikota untuk melakukan pembinaan dan pengawasan terhadap kegiatan usaha pertambangan. Dalam melakukan usaha pertambangan harus memenuhi berbagai ketentuan di antaranya adalah mendapat izin dari Pemerintah Daerah setempat. Hal ini didasari pada pemikiran bahwa Pemerintah Daerah yang mempunyai wilayah dan dapat melakukan pengawasan terhadap usaha pertambangan.

\footnotetext{
${ }^{2}$ Sumber Data Dinas Pertambangan Dan Energi Kabupaten Alor, Tahun 2015

${ }^{3}$ Salim HS. (2014). Hukum Pertambangan Mineral dan Batubara. Jakarta:Sinar Grafika. hlm. 62.

${ }^{4}$ Undang -Undang N0 4 Tahun 2009 Pasal 139.
} 
Perizinan merupakan instrumen utama dalam implementasi program-program Pemerintah Daerah yang merupakan bagian internal dari penyelenggaraan urusan-urusan pemerintahan, maka Pemerintah Daerah dapat secara lebih khusus untuk menggunakan kewenangannya sesuai dengan perundang-undangan yang berlaku. Namun jenis dan prosedur perizinan di Indonesia masih beraneka ragam, rumit dan sukar ditelusuri sehingga merupakan hambatan bagi kegiatan dunia usaha. Jenis perizinan di negara kita sedemikian banyaknya dan Waller menamakan Indonesia sebagai een verguningland (negara perizinan). ${ }^{5}$

Sejalan dengan perkembangan masyarakat dengan berlakunya Peraturan Pemerintah Nomor 2 Tahun 2014 tentang Pemerintah Daerah bahwa Pemerintah Daerah tidak lagi mengeluarkan izin tambang yang dituangkan dalam lampiran UU Nomor 23 Tahun 2014 atas pembagian urusan pemerintahan bahwa Bupati dan Walikota tidak lagi berwenang menetapkan Wilayah Usaha Pertambangan (WUP) serta Izin Usaha Pertambangan(IUP) ke perusahaan. Kewenangan itu kini dimiliki oleh gubernur dan pemerintah pusat. Pencabutan kewenangan pemberian izin dari pemerintah kabupaten ke pemerintah provinsi tidak memberikan solusi bagi persoalan di daerah, oleh karena izin tambang yang dikeluarkan oleh pemerintah daerah bertentangan dengan pasal 26 Peraturan Pemerintah Nomor 23 Tahun 2010.

Memperhatikan peraturan perundang-undangan yang berlaku di Indonesia baik UndangUndang Nomor 4 Tahun 2009 tentang Pertambangan Mineral dan Batubara maupun UndangUndang Nomor 32 Tahun 2009 tentang Perlindungan dan Pengelolaan Lingkungan Hidup (UUPPLH) menjadikan landasan untuk menyelesaikan semua permasalahan di bidang lingkungan hidup, mulai dari pelanggaran hukum dan kerusakan lingkungan yang tidak dapat dikendalikan sampai berujung pada tekanan dan kekerasan yang menyampingkan kepentingan masyarakat untuk hidup aman dan sejahtera.

Kerusakan lingkungan membawa dampak yang serius bagi kehidupan masyarakat karena hilangnya sumber daya alam, namun kerusakan yang paling parah berada daerah pertambangan dan lingkar tambang bahkan di dalam pengelolaan dan pemantauan lingkungan hidup yang dilakukan oleh pelaku usaha. Berdasarkan uraian di atas, permasalahan dalam penelitian ini ialah; pertama, bagaimanakah pola pengaturan perizinan pengelolaan tambang dalam mendukung pembangunan berkelanjutan di Kabupaten Alor, kedua, bagaimanakah tanggung jawab pemegang Izin Usaha Pertambangan terhadap perubahan kualitas lingkungan hidup.

\section{B. METODE PENELITIAN}

Penelitian ini merupakan penelitian hukum normatif atau doktrinal yaitu penelitian terhadap data sekunder yang berupa bahan hukum primer, bahan hukum sekunder, dan bahan hukum tersier. Selain itu, penelitian ini menggunakan metode pendekatan undang-undang, ${ }^{6}$ pendekatan kasus, ${ }^{7}$ dan pendekatan konsep ${ }^{8}$ yang akan dianalisis secara yuridis preskriptif. Analisisnya melalui interpretasi dengan tetap memperhatikan konsistensi antara teori hukum, asas hukum dan kaidah hukum yang relevan dengan permasalahan dalam penelitian ini.

\section{PEMBAHASAN}

\section{Pola Pengaturan Perizinan Pengelola Tambang}

Pengelolaan tambang berdasarkan UU Nomor 4 Tahun 2009 tentang Pertambangan Mineral dan Batubara diatur dalam Pasal 1 ayat 7 (tujuh) yang menyatakan bahwa Izin Usaha Pertambangan (IUP) adalah izin untuk melaksanakan usaha pertambangan. Dijabarkan lebih

${ }^{5}$ Siti Sundari Rangkuti. (2000). Hukum Lingkungan dan Kebijakan Lingkungan Nasional. Edisi kedua. Surabaya:Airlangga University Press. hlm 142.

${ }^{6}$ Peter Mahmud Marzuki.(2005).Penelitian Hukum. Jakarta:Kencana Prenadia Group. hlm. 136

${ }^{7}$ Ibid., hlm. 158

${ }^{8}$ Ibid., hlm. 177

272 Irianti Takalapeta, Jimmy Pello \& Saryono Yohanes | Pengaturan Perizinan .... 
lanjut dalam Peraturan Pemerintah Nomor 23 Tahun 2010 tentang Pelaksanaan Kegiatan Usaha Pertambangan Mineral dan Batubara yang diatur dalam pasal 6 tentang Izin Usaha Pertambangan. Untuk dapat diterbitkannya IUP, baik IUP Eksplorasi maupun IUP Operasi Produksi maka pemohon IUP harus memenuhi persyaratan yang telah ditentukan dalam peraturan perundang-undangan. Adapun persyaratan yang harus dipenuhi oleh pemohon untuk mengajukan IUP yang meliputi administrasi, teknis, lingkungan dan finansial Peraturan Pemerintah Nomor 55 Tahun 2010 juga mengatur tentang Pembinaan dan Pengawasan Penyelenggaraan Pengelolaan Usaha Tambang Mineral dan Batubara.

Di samping Peraturan Pemerintah, Pasal 4 Peraturan Daerah Nusa Tenggara Timur juga mengatur tentang Pengelolaaan Bahan Tambang yang ditindaklanjuti dengan Pasal 2 Peraturan Daerah Kabupaten Alor tentang Ruang Lingkup Pengelolaan Kewenangan dan Pengelolaan Bahan Tambang. IUP merupakan izin yang diberikan kepada pemegang izin untuk melakukan suatu kegiatan pertambangan yang meliputi pertambangan mineral dan pertambangan batubara. Pertambangan mineral adalah pertambangan kumpulan mineral yang berupa bijih atau batuan, di luar panas bumi, minyak dan gas bumi serta air tanah, sedangkan pertambangan batubara adalah pertambangan endapan karbon yang terdapat di dalam bumi, termasuk bitumen padat, gambut dan batuan aspal, sementara itu jenis IUP yang diberikan untuk melakukan kedua kegiatan yaitu IUP Eksplorasi dan IUP Operasi Produksi.

Lebih lanjut, menjalankan fungsi hukum memerlukan berbagai perangkat dengan tujuan agar hukum memiliki kinerja yang baik. Salah satu kinerja yang membedakan dengan yang lain adalah bahwa hukum memiliki kaidah yang bersifat memaksa, artinya apabila kaidah hukum dituangkan ke dalam sebuah perundang-undangan maka setiap orang harus melaksanakannya. Selain untuk mengendalikan setiap kegiatan atau perilaku individu atau kolektivitas yang sifatnya preventif adalah melalui izin. Izin merupakan suatu keputusan administrasi negara yang memperkenankan suatu perbuatan yang pada umumnya dilarang, tetapi diperkenankan dan bersifat konkrit. ${ }^{9}$

Bidang usaha pemanfaatan lahan untuk usaha pertambangan aparat pemerintah bertugas untuk mengawasi dan membina usaha pertambangan adalah pemerintah daerah sejalan dengan bergulirnya otonomi daerah seperti yang termuat dalam pasal 14 UU No. 32 Tahun 2014 tentang pemerintahan daerah yang menyatakan bahwa urusan wajib yang menjadi kewenangan pemerintah daerah untuk kabupaten/kota yakni pengendalian lingkungan hidup. Perizinan merupakan instrumen lingkungan hidup yang mempunyai fungsi preventif, yaitu mencegah terjadinya pencemaran dan kerusakan lingkungan melalui izin pemerintah dapat menetapkan syarat-syarat lingkungan yang harus dipenuhi oleh pemilik kegiatan.

\section{Izin Lingkungan}

Izin lingkungan yang termuat dalam UU No. 32 Tahun $2009,{ }^{10}$ menggabungkan proses pengurusan keputusan kelayakan lingkungan hidup diurus di awal kegiatan usaha. Analisis Mengenai Dampak Lingkungan (Amdal) atau Upaya Pengelolaan Lingkungan hidup (UKL), dan Upaya Pemantauan Lingkungan Hidup (UPL) tanpa ketiga dokumen tersebut, izin lingkungan tidak akan diberikan. Penyelenggaraan izin usaha tambang erat hubungannya dengan izin lingkungan hidup karena berkaitan pencegahan seperti AMDAL, UKL dan UPL.

${ }^{9}$ Juniarso Ridwan dan Achmad Sodik Sudrajat. (2010). Hukum Administrasi Negara Dalam Kebijakan Publik. Jakarta:Nuansa. hlm90 .

${ }^{10}$ Peraturan Pemerintah No 23 Tahun 2010 


\section{Permohonan Izin Usaha Tambang}

Pasal 39 Undang-Undang Nomor 4 Tahun 2009 telah ditentukan subtansi atau hal-hal yang wajib dimuat dalam IUP Eksplorasi dan IUP Produksi. Di dalam Pasal 35 UU Minerba mengatakan usaha pertambangan sebagaimana dimaksud dalam pasal 34 dilaksanakan dalam bentuk IUP, IPR dan IPK. Pasal 1 butir UU minerba menyatakan izin usaha pertambangan (IUP) adalah izin untuk melaksanakan usaha pertambangan yaitu: Izin Usaha Pertambangan (IUP) adalah izin usaha pertambangan yang dilakukan oleh Menteri, Gubernur dan Bupati sesuai kewenangannya. Prinsip pemberian izin pertambangan diatur dalam UU No. 4 Tahun 2009 adalah IUP hanya diperbolehkan untuk satu jenis tambang mineral atau batubara. Penyimpangan terhadap prinsip tersebut dimungkinkan hal ini dapat terjadi apabila orang yang sudah diberikan IUP pada waktu melakukan pertambangan menemukan mineral lain di dalam IUP yang oleh pemerintah untuk mengusahakannya. Apabila pemegang IUP bermaksud mengusahakan mineral lain yang ditemukannya, maka pemegang IUP wajib melakukan permohonan IUP baru kepada pejabat yang berwenang. Jika pemegang IUP tidak berminat untuk mengusahakan mineral yang ditemukan tersebut maka yang bersangkutan berkewajiban untuk menjaga mineral lain tersebut.

\section{Persyaratan Izin Usaha Tambang}

Bertitik tolak dari pengertian izin usaha tambang serta tujuannya, maka untuk memperoleh izin usaha tambang pemohon harus memenuhi berbagai persyaratan administrasi, teknis, lingkungan dan finansial yang diatur dalam pasal 25, 26, 27 PP No. 23 Tahun 2010 antara lain:

1. Persyaratan administrasi sebagaimana dimaksud dalam pasal 23 huruf (a) untuk perusahaan firma dan perusahaan komanditer meliputi Pasal 24 ayat 4 Peraturan Pemerintah No. 23 Tahun 2010.

a. Untuk IUP eksplorasi dan IUP produksi mineral logam dan batu bara yaitu:

1. surat permohonan;

2. susunan pengurus dan daftar pemegang saham dan;

3. surat keterangan domisili.

b. Untuk IUP eksplorasi dan IUP produksi mineral bukan logam dan batubara:

1. surat permohonan;

2. profil perusahaan;

3. akte pendirian perusahaan yang bergerak di bidang usaha pertambangan;

4. nomor pokok wajib pajak;

5. susunan pengurus dan daftar pemegang saham; dan

6. surat keterangan domisili.

2. Persyaratan teknis diatur dalam Pasal 25 yaitu:

a. IUP eksplorasi meliputi:

1. daftar riwayat hidup dan surat pernyataan tenaga ahli pertambangan dan/atau geologi yang berpengalaman paling sedikit 3 (tiga) tahun;

2. peta wilayah IUP yang dilengkapi dengan batas koordinat geografis lintang dan bujur sesuai dengan ketentuan sistem informasi geografi yang berlaku secara nasional.

b. IUP produksi meliputi:

1. peta wilayah dilengkapi dengan batas wilayah koordinat geografis lintang dan bujur sesuai dengan ketentuan sistem informasi geografi yang berlaku secara nasional;

2. laporan lengkap eksplorasi;

3. laporan studi kelayakan;

4. rencana reklamasi dan pasca tambang;

5. rencana kerja dan anggaran biaya; 
6. rencana pembangunan sarana dan prasarana penunjang kegiatan operasi produksi; dan

7. tersedianya tenaga ahli pertambangan dan/atau geologi yang berpengalaman paling sedikit 3 (tiga) tahun.

3. Persyaratan lingkungan sebagaimana dimaksud dalam pasal 23 huruf c meliputi:

a. untuk IUP eksplorasi meliputi pernyataaan untuk memenuhi ketentuan peraturan perundang-undangan di bidang perlindungan dan pengelolaan lingkungan hidup;

b. untuk IUP operasi produksi meliputi:

1. pernyataan kesanggupan untuk mematuhi ketentuan peraturan perundang-undangan di bidang perlindungan dan pengelolaan lingkungan hidup; dan

2. persetujuandokumenlingkunganhidupsesuaidenganketentuanperaturanperundangundangan yang berlaku.

4. Persyaratan finansial sebagaimana dimaksud dalam Pasal 23 huruf $d$ adalah:

a. IUP produksi meliputi:

1. bukti pendapatan jaminan kesanggupan pelaksanaan kegiatan eksplorasi; dan

2. bukti pembayaran harga nilai kompensasi data informasi hasil lelang mineral logam atau batu bara sesuai dengan nilai penawaran lelang atau bukti pembayaran biaya pencadangan wilayah dan pembayaran pencetakan peta WIUP mineral bukan logam atau batuan atas permohonan wilayah.

b. IUP produksi meliputi:

1. laporan keuangan tahun terakhir yang telah didebit oleh akun publik;

2. bukti pembayaran iuran tetap 3 (tiga) tahun terakhir; dan

3. bukti pembayaran pengganti investasi sesuai dengan nilai penawaran lelang bagi pemegang lelang IUP yang telah berakhir;

4. ketentuan lebih lanjut mengenai jaminan kesanggupan diatur dengan peraturan menteri.

Berdasarkan penyampaian di atas, penulis berargumentasi bahwa setiap usaha atau kegiatan yang berdampak penting terhadap lingkungan wajib memiliki amdal karena di dalam kehidupan manusia selalu berhubungan dengan lingkungan. Apabila lingkungan tidak dijaga maka kehidupan manusia akan terganggu, selain itu syarat utama sebuah izin usaha harus memenuhi criteria administrasi, teknis, lingkungan dan finansial. Fakta di lapangan menunjukkan bahwa di Kabupaten Alor pelaksanaannya tidak sesuai dengan undang-undang yang berlaku.

\section{Pelaksanaan Izin Usaha Tambang di Kabupaten Alor}

Undang-Undang No. 4 Tahun 2009 yang mengatur tentang mineral dan batu bara memberikan pedoman bahwa pengelolaan dan pengusahaan pertambangan yang merupakan tata ruang nasional harus dikelola secara baik dan bertanggung jawab sehingga dapat memberi konstribusi bagi negara terutama untuk kesejahteraan rakyat. Dalam ketentuan pasal 27 Undang-Undang ini diatur juga tentang penetapan wilayah pertambangan yaitu wilayah usaha pertambangan, wilayah usaha pertambangan rakyat dan wilayah usaha pertambangan khusus yang dilakukan secara transparan, akuntabel, dengan melibatkan seluruh elemen pemerintah pusat, pemerintah daerah, DPR/DPRD, dan masyarakat.

Penetapan wilayah pertambangan sebagaimana yang diamanatkan oleh Undang-Undang No. 4 Tahun 2009 diharapkan akan berpengaruh positif terhadap kondisi pengolahan dan pengusahaan bahan galian ke depan sehingga dapat mendorong dampak positif bagi daerah sebagai berikut: 
1. mendorong tumbuh kembangnya usaha pertambangan, baik investasi asing, nasional maupun lokal;

2. mendorong gairah partisipasi masyarakat setempat untuk mengelola dan mengusahakan bahan galian yang ada;

3. mendorong gairah kegiatan penunjang dan pertumbuhan ekonomi lokal;

4. meningkatkan pendapatan negara dan daerah;

5. terbukanya lapangan kerja baru;

6. menekan dampak negatif kerusakan lingkungan yang selama ini terjadi akibat dari beragam legalitas dari usaha pertambangan, yang menyebabkan saling tuding menuding kewenangan antara tingkatan pemerintahan yang kerap terjadi;

7. memudahkan pengawasan dan pembinaan dari pemerintah.

Legalitas izin usaha pertambangan menurut Undang-Undang Nomor 4 Tahun 2009 diatur dalam Pasal 36 tentang Izin Usaha Tambang, dalam melakukan usaha pertambangan pengusaha wajib mengantongi Keputusan Bupati Alor tentang Izin Usaha Pertambangan sebagai pedoman pelaksanaan usaha/ kegiatan tambang.

Untuk pengurusan perizinan usaha tambang membutuhkan waktu yang panjang untuk proses penetapan keputusan yang melalui beberapa tahap:

1. pengajuan permohonan untuk mendapat izin usaha pertambangan oleh pengusaha dilengkapi dengan seluruh persyaratan yang diperlukan (sesuai dengan Peraturan Daerah Kabupaten Alor Nomor 9 Tahun 2011);

2. jika telah lengkap seluruh kelengkapannya dibuat draft keputusan oleh Dinas Pertambangan dan Energi Kabupaten Alor diajukan ke Bupati Alor melalui bagian $\mathrm{Hu}-$ kum dan HAM Sekretaris Daerah Kabupaten Alor;

3. setelah diperiksa/diteliti secara seksama dalam konteks hukum terhadap keputusan barulah diajukan ke Bupati untuk disetujui draft keputusan;

4. pengetikan kembali konsep keputusan yang telah disetujui dan diajukan kembali ke Bupati untuk penandatanganan.

\section{Pengawasan dan Pengendalian Tambang terhadap Kerusakan Lingkungan Hidup}

Kegiatan usaha tambang dalam menunjang pembangunan fisik serta meningkatkan taraf hidup, namun dalam pelaksanaannya menimbulkan dampak kerusakan lingkungan seperti terjadi banjir, longsor yang menyebabkan kerugian materi maupun keselamatan kerja. Banyak kerusakan lahan sebagai dampak eksplorasi oleh pelaku usaha/kegiatan pertambangan khusus galian c di Kabupaten Alor, sedikit banyak telah merubah bentuk lahan yang sejak dahulu dijaga kelestariannya.

Sodikin, berpendapat bahwa kerusakan lingkungan hidup merupakan kemunduran lingkungan yang ditandai dengan hilangnya sumber daya tanah, air, punahnya fatwa liar dan kerusakan ekosistem. Kerusakan lingkungan merupakan salah satu ancaman yang berbahaya untuk kelangsungan hidup manusia yang berpotensi menghasilkan bencana untuk saat ini dan masa yang akan datang.

Undang-Undang Nomor 4 Tahun 2009 tentang Usaha Pertambangan diterbitkan di era Otonomi Daerah. Dengan adanya Undang-Undang Nomor 32 Tahun 2004 di mana daerah diberikan kewenangan untuk mengatur dan mengurus wilayahnya termasuk bidang perizinan. 
Pemerintah Daerah yang diberi kewenangan mengeluarkan perizinan dalam hal Izin Usaha Pertambangan (IUP) terkesan longgar dalam menetapkan prosedur yang seharusnya dilaksanakan sebelum diterbitkannya IUP.

Sebelum menerbitkan IUP harus terlebih dahulu melewati tahapan izin lingkungan yaitu izin yang diberikan kepada setiap orang yang melakukan usaha dan/atau kegiatan yang wajib Amdal atau UKL-UPL dalam rangka perlindungan dan pengelolaan lingkungan hidup sebagai syarat memperoleh izin usaha dan kegiatan. Persyaratan administrasi merupakan salah satu alat kontrol bagi pemerintah daerah agar tidak terjadi perusakan lingkungan di wilayahnya. Kenyataan saat ini pemberian izin pertambangan menjadi obyek dari pada pengusaha tambang untuk mendapatkan keuntungan sebesar-besarnya tanpa memperhitungkan dampak yang akan terjadi terhadap kerusakan lingkungan akibat dari kegiatan pertambangan. Peneliti melakukan pengamatan langsung kebeberapa lokasi tambang yang ada di Wakabsir, Wakabsir Timur (Bomara).

Fanating, Likwatang, Lembur Timur telah terjadi kerusakan lingkungan akibat dari aktifitas eksplorasi dan galian c. Pelaksanaan pemanfaatan Sumber Daya Alam yang menjadi kewenangan pemerintah daerah yang termuat dalam UU Nomor 32 Tahun 2004 meliputi: pertama, kewenangan tanggung jawab, pemanfaatan, pengendalian dampak, budi daya dan pelestarian; kedua, bagi hasil atas pemanfaatan sumber daya; ketiga, penyeserasian bagi tata ruang serta rehabilitasi lingkungan. Ketiga butir tersebut menegaskan tentang kewenangan pemanfaatan sumber daya alam sekaligus melihat kewenangan untuk pengendalian dampak dan melestarikan sumber daya alam.

Kewenangan pemanfaatan sumber daya pertambangan oleh kepada daerah sudah sewajarnya dilakukan dengan demikian daerah dapat memanfaatkannya bagi kesejahteraan masyarakat. Dalam Pasal 72 UU Nomor 32 Tahun 2009 menyatakan bahwa Bupati/Wali Kota wajib melakukan pengawasan ketaaatan penanggung jawab usaha/kegiatan, dengan demikian aktivitas yang tercantum dalam dokumen Amdal, UKL-UPL dapat dimonitor pelaksanaannya.

Apabila dicermati dengan seksama, kekayaan alam yang ada dan dimiliki oleh negara yang kesemuanya ini mempunyai nilai ekonomis, maka dalam pemanfaatanpun harus diatur dan dikembangkan dalam pola tata ruang yang terkoordinasi, sehingga tidak akan adanya perusakan terhadap lingkungan hidup. Upaya pelaksanaan perencanaan tata ruang yang bijaksana adalah kunci dalam pelaksanaan tata ruang agar tidak merusak lingkungan hidup, dalam konteks penguasaan negara atas dasar sumber daya alam melekat di dalam kewajiban negara untuk melindungi, melestarikan dan memulihkan lingkungan hidup secara utuh. Artinya aktivitas pembangunan yang dihasilkan dari perencanaan tata ruang pada umumnya bernuansa pemanfaatan sumber daya alam tanpa merusak lingkungan.

Selanjutnya dalam mengomentari konsep Roscou Pound, Mochtar Koesoemaatmadja mengemukakan bahwa hukum haruslah menjadi sarana pembangunan. ${ }^{11}$ Di sini berarti hukum haruslah mendorong proses modernisasi, artinya hukum yang dibuat haruslah sesuai dengan cita-cita keadilan sosial bagi seluruh rakyat Indonesia. Sejalan dengan fungsi tersebut maka pembentuk undang-undang meletakkan berbagai dasar yuridis dalam melakukan berbagai kegiatan pembangunan, sebagai salah satunya yaitu dalam pembuatan undang-undang mengenai penataan ruang.

Undang-Undang Nomor 26 Tahun 2007 merupakan undang-undang pokok yang mengatur pelaksanaan penataan ruang. Keberadaan undang-undang tersebut diharapkan sebagai konsep dasar hukum dalam melaksanakan perencanaan tata ruang, juga diharapkan dapat digunakan sebagai bahan acuan pemerintah dalam penataan dan pelestarian lingkungan hidup.

${ }^{11}$ Mochtar Koesoemaatmaja. (2012). Teori Hukuk Pembangunan, Eksistensi dan Implikasi. Jakarta. hlm. 45. 
Aktivitas pembangunan dan pemanfaatan sumber daya alam, merupakan peristiwa fisik yang terjadi di lingkungan tersebut, yang banyak mengubah atau berpengaruh kepada daerah yang bersangkutan. Pemanfaatan sumber daya alam selain membawa pengaruh yang positif juga dapat menimbulkan pengaruh yang negatif, yaitu terjadinya kerusakan alam sebagai akibat pengambilan sumber daya alam yang jauh lebih cepat dari waktu yang diperlukan untuk terbentuknya kekayaan alam tersebut. Kondisi ini menyebabkan adanya penurunan kualitas daya dukung lingkungan, yang merupakan faktor terpenting dalam menunjang kelangsungan kehidupan manusia dan makhluk lainnya. Konsep lingkungan hidup dilakukan melalui pendekatan pembangunan yang berkelanjutan, seimbang, serasi selaras untuk kesejahteraan masyarakat demi kepentingan generasi kini dan akan datang. Pengaturan tata ruang di Indonesia mendapat momentum saat disahkan tentang penataan ruang yang selanjutnya dilakukan revisi Rencana Tata Ruang Wilayah (RTRW) dengan mempertimbangkan aspek lingkungan hidup.

Instrumen tata ruang wilayah merupakan jawaban terhadap persoalan universal dari tuntutan masyarakat dalam memenuhi berbagai kebutuhan sumber daya alam, khususnya tanah. Dalam memenuhi kebutuhan tanah untuk berbagai macam kegiatan secara konseptual harus ditata dan diarahkan sesuai dengan jenis dan/atau kegiatan usahanya masing-masing. Konsep ini selain untuk menciptakan keserasian, juga menciptakan perlindungan dan kenyamanan.

Tata ruang dan kerusakan lingkungan merupakan suatu konsep yang tidak dapat dipisahkan beberapa tahun terakhir muncul dan memberi peringatan mengenai ancaman keberlanjutan pembangunan daerah. Dalam hal ini diperlukan pemikiran jauh ke depan yang tidak berorientsi kepada pemenuhan pada tujuan jangka pendek, dan perlu reorientasi visi pembangunan daerah dan lebih mempertimbangkan faktor lingkungan dan pembangunan berkelanjutan.

Rencana Tata Ruang Wilayah (RTRW) di Kabupaten Alor diatur dalam Peraturan Daerah Nomor 2 Tahun 2013 tentang Rencana Tata Ruang Kabupaten Alor Tahun 2013-2033. Strategi penataan ruang Kabupaten Alor diatur dalam Pasal 4 Perda No 2 Tahun 2013 meliputi:

a. Pengembangkan sentra produksi pertanian, perkebunan yang berbasis sumber daya alam daratan dan laut.

b. Pengembangan sentra produksi potensial yang berbasis sumber daya alam dilakukan secara berkelanjutan.

c. Untuk peningkatan pemanfaatan sumber daya alam yang memberikan nilai tambah melalui agroindustri dan agribisnis melalui pengembangan agropolitan dan minapolitan

d. Pengembangan prasarana guna menjangkau seluruh wilayah.

e. Pelestarian pemanfaatan fungsi lingkungan hidup dalam rangka pembangunan berkelanjutan.

f. Penataan wilayah rawan bencana.

g. Peningkatan fungsi kawasan untuk kepentingan pertahanan dan keamanan negara.

h. Pengelolaaan wilayah perbatasan yang mendukung pertahanan dan keamanan nasional.

Selain fungsi tata ruang yang telah diuraikan di atas, namun dalam pelaksanaannya belum berjalan seperti penjelasan yang disampaikan oleh Kaban BPM Perizinan Terpadu pada rapat evaluasi tanggal 9 Desember 2016 yang mengharapkan agar Bagian Sumber Daya Alam SETDA Kabupaten Alor memfasilitasi penetapan wilayah pertambangan rakyat galian $\mathrm{C}$, juga sampai saat ini BPM dan Perizinan Terpadu Kabu- 
paten Alor belum mendapat pelimpahan kewenangan untuk mengeluarkan izin terkait penambangan rakyat dan hanya terbatas pada SITU, SIUP dan IMB.

Peraturan perundang-undangan dalam penataan ruang perlu disinkronkan oleh Bupati untuk menjadi acuan semua pihak termasuk masyarakat dalam membuat tata ruang wilayah dan/ atau kota, kawasan pesisir laut serta daerah aliran sungai sehingga dampak lingkungan akibat kerusakan lingkungan dapat dikurangi atau ditiadakan.

\section{Tanggung Jawab Perusahaan terhadap Perubahan Kualitas Lingkungan Hidup}

Suatu perusahaan yang melakukan usaha dan/atau kegiatan di wilayah tertentu akan menimbulkan berbagi dampak terhadap masyarakat maupun lingkungan dan memiliki tanggung jawab yang berbeda terhadap kegiatan yang dilakukannya. Kesanggupan memenuhi ketentuan pengelolaan lingkungan hidup penting karena kegiatan penambangan pasti akan menimbulkan kerusakan terhadap lingkungan hidup sehingga diperlukan komitmen dari pengusaha agar meminimalisir kerusakan lingkungan, dan bila terjadi kerusakan maka perlu pengelolaan lingkungan yang tepat sehingga dapat memberi manfaat bagi masyarakat baik untuk generasi sekarang maupun generasi yang akan datang. Apabila perusahaan tidak mematuhi pernyataan yang dibuat maka akan dikenakan sanksi.

Melihat keseluruhan ketentuan yang diatur dalam UUPPLH maka dapat dikualifikasikan bentuk pertanggungjawaban antara lain pertanggungjawaban administrasi, pertanggungjawaban perdata dan pertanggungjawaban pidana:

\section{Tanggung Jawab Administrasi}

Perusahan yang melakukan kegiatan memerlukan suatu kepastian hukum untuk menjalankan usahananya. Di dalam pengelolaannya membutuhkan peran serta pemerintah untuk mengawasi dan mengendalikan setiap kegiatan yang dilakukan oleh pengusaha. UUPPLH mengatur ketentuan yang berwawasan lingkungan oleh karena itu suatu perusahaan yang melakukan proses produksinya wajib memperhatikan situasi dan kondisi lingkungan sekitarnya. Jika terjadi pelanggaran yang menyebabkan kerusakan dan pencemaran lingkungan maka kepada perusahaan tersebut dapat diminta pertanggungjawaban.

Untuk itu berkaitan dengan tugas dan tanggung jawab pemerintah secara konstitusional pemerintah wajib mencabut izin tersebut. Pasal 76 UUPPLH mengatur tentang tanggung jawab administrasi perusahaan yaitu:

\section{a. Teguran tertulis}

Sanksiadministratifberupategurantertulisditerapkankepadapenanggungjawabusaha dan/atau kegiatan yang telah melakukan pelanggaran peraturan perundang-undangan dan persyaratan yang ditentukan dalam izin lingkungan. Namun dalam pelaksanaan dalam tata kelola lingkungan maupun secara tekinis masih dapat dilakukan perbaikan dan belum menimbulkan dampak negatif terhadap lingkungan hidup berupa:

1. Tidak menyampaikan laporan;

2. Belum menunjukan pelanggaran terhadap baku kerusakan lingkungan hidup;

3. Bersifat teknis, tidak melakukan penggunaan teknologi tinggi, tidak memerlukan penanganan oleh ahli dan tidak memerlukan biaya yang tinggi.

b. Paksaan pemerintah

Paksaan pemerintah adalah sanksi administratif berupa tindakan nyata untuk menghentikan pelanggaraan dan/atau memulihkan dalam keadaan semula penerapan sanksi paksaan dapat dilakukan terhadap penanggungjawab usaha dan/atau kegiatan dengan terlebih dahulu diberikan tegutan tertulis. Adapun sanksi paksaan pemerintah 
dapat juga dijatuhkan tampa diketahui dengan teguran tertulis, apabila pelanggaran yang dilakukan menimbulkan:

1. Ancaman yang sangat serius bagi manusia dan lingkungan.

2. Dampak lebih besar dan lebih luas jika tidak segera dihentikan pencemaran dan/atau kerusakannya.

3. Kerugian lebih besar bagi lingkungan hidup jika tidak segera dihentikan.

\section{Tanggung Jawab Perdata}

Menurut Pasal 1 angka (5) Peraturan Pemerintah Nomor 13 Tahun 2011 tentang Ganti Rugi terhadap Pencemaran dan/atau Kerusakan Lingkungan. Ganti rugi adalah biaya yang harus ditanggung oleh penanggung jawab kegiatan dan/atau usaha akibat terjadinya pencemaran dan/atau kerusakan lingkungan. ${ }^{12}$

Menurut Pasal 87 ayat (1) UU Nomor 32 Tahun 2009 tentang Perlindungan dan Pengelolaan Lingkungan Hidup, bahwa setiap penanggung jawab usaha dan /atau kegiatan yang melakukan perbuatan melanggar hukum berupa pencemaran atau kerusakan lingkungan hidup yang menimbulkan kerugian pada orang lain atau lingkungan hidup wajib membayar ganti rugi dan/atau melakukan tindakan tertentu. Di dalam hukum perdata mengatur tentang ganti rugi akibat perbuatan melawan hukum. Perbuatan melawan hukum adalah satu perbuatan yang dilakukan oleh salah satu pihak atau lebih telah merugikan pihak lain. Perbuatan melanggar hukum yang dilakukan oleh salah satu pihak atau lebih baik dilakukan yang haknya dilanggar (Pasal 1365 KUH Perdata). Yang dimaksud perbuatan melanggar hukum menurut Pasal 1365 KUH Perdata adalah tiap perbuatan melanggar hukum yang membawa kerugian pada orang lain, mewajibkan karena kesalahannya menimbulkan kerugian dan mengganti kerugian tersebut.

Untuk setiap orang atau badan hukum yang melakukan perbuatan melawan hukum (pencemaran/ kerusakan lingkungan) harus bertanggung jawab terhadap kerugian yang dialami oleh masyarakat maupun pemerintah serta pihak lainnya, yang dimaksud dengan perbuatan melanggar hukum menurut pasal 1365 KUH Perdata adalah tiap perbuatan melanggara hukum yang membawa kerugian pada orang lain, mewajibkan karena kesalahan nya menerbitkan kerugian itu, mengganti kerugian tersebut. Untuk setiap orang atau badan hukum yang melakukan perbuatan melanggar hukum ( pencemaran/kerusakan lingkungan) harus bertanggung jawab atas kerugian yang dialami oleh masyarakat maupun pemerintah serta pihak lain.

Secara keseluruhan pengaturan tentang kerugian bagi lingkungan hidup diatur dalam Pasal 3 s/d Pasal 8 UUPPLH. Untuk pemberian ganti rugi dapat dilakukan melalui gugatan ke pengadilan dan telah mendapat kekuatan hukum yang tetap.

\section{Tanggung Jawab Pidana}

Memberikan efek jera kepada pelaku usaha yang melanggar ketentuan dalam hukum lingkungan melalui hukuman badan atau denda kepada individu, maupun korporasi/badan hukum yang usahanya mengakibatkan pencemaran dan/atau kerusakan lingkungan hidup. Seorang atau badan hukum yang melakukan tindak pidana wajib mempertanggungjawabkan perbuatannya. Pasal 116 s/d 120 UUPPLH mengatur tentang pertanggungjawaban pidana terhadap perusahaan yang melakukan perusakan atau pencemaran lingkungan. Untuk menentukan siapa yang harus memikul beban pertanggungjawaban pidana, maka Pasal 46 UUPPLH menjadi konsep pertanggungjawaban pidana korporasi di bidang lingkungan hidup yang dikenakan kepada badan hukum atau pengurusnya (Direktur, Manager yang bertanggung

\footnotetext{
${ }^{12}$ Peraturan Pemerintah No.13 Tahun 2011
} 
jawab dalam pengelolaan lingkungan hidup bahkan kepada pemegang saham, maupun para komisaris) yang secara bersama-sama dalam hal kegiatan atau usaha korporasi tersebut menyebabkan pencemaran dan kerusakan lingkungan. ${ }^{13}$

\section{KESIMPULAN}

Pemberian izin pertambangan di Kabupaten Alor pada umumnya belum berjalan sesuai dengan peraturan perundang-undangan yang berlaku sehingga, mengakibatkan adanya pelanggaran terhadap izin lingkungan khususnya pada izin eksplorasi tambang timah hitam di Wakabsir dan Wakabsir Timur serta galian c yang berada di pesisir pantai dan daerah aliran sungai, hanya memenuhi persyaratan administrasi dan teknis tanpa persyaratan lingkungan dan finansial yang merupakan syarat utama untuk mendapatkan izin eksplorasi, sanksi yang diberikan terhadap pelanggaran yang dilakukan oleh pengusaha dan masyarakat yang tidak memiliki izin lingkungan masih bersifat sanksi administrasi.

Pelaksanaan pembinaan dan pengawasan sebagai bentuk penegakan hukum dari Pemerintah Daerah dalam hal ini instansi teknis terkait kepada pengusaha tambang belum dilakukan secara efektif sehingga belum mampu membangun kesadaran hukum secara utuh juga kurang adanya koordinasi di antara lembaga sehingga memberi peluang kepada pengusaha tambang untuk terus melakukan aktivitasnya yang dianggap benar.

Saran yang diberikan oleh penulis adalah pemberian izin pengelolaan tambang dalam menunjang pembangunan berkelanjutan di Kabupaten Alor harus melibatkan dinas terkait untuk melakukan sosialisasi tentang hak dan kewajiban dan sanksi yang akan diberikan kepada perusahaan yang akan melakukan usaha tambang juga memberikan ruang bagi masyarakat untuk bersama pemerintah melakukan pengawasan.

Harus dibuat perda khusus tentang pemberian lingkungan hidup, serta penetapan wilayah pertambangan galian C yang berikan oleh Kantor Izin Pelayanan Terpadu Satu Pintu untuk memudahkan pemantauan dan pengawasan kegiatan berupa laporan kegiatan, perkembangan perusahaan dalam menyelesaikan kewajiban-kewajiban atau persoalan yang menyangkut dengan kerusakan lingkungan kepada pemerintah daerah sehingga tim yang dibentuk dapat melakukan pengawasan demi tercapainya peningkatan penerimaan asli daerah dan menjaga kelestarian lingkungan hidup.

\section{DAFTAR PUSTAKA}

\section{Buku}

H.S., Salim. (2013).Hukum Pertambangan Indonesia. Jakarta:Raja Grafindo Persada

Ridwan, Juniarso dan Achmad Sodik Sudrajat. (2010). Hukum Administrasi Negara dalam Kebijakan Publik. Jakarta: Nuansa.

Kusumaatmadja, Mochtar. (2012). Teori Hukum Pembangunan, Eksistensi dan Implikasi. Jakarta.

HS., Salim. (2014). Hukum Pertambangan Mineral dan Batubara. Jakarta: Sinar Grafika.

Rangkuti, Siti Sundari. (2000). Hukum Lingkungan dan Kebijakan Lingkungan Nasional. Edisi kedua. Surabaya: Airlangga University Press.

Marzuki, Peter Mahmud. (2005). Penelitian Hukum. Jakarta: Kencana Prenadia Group.

\footnotetext{
${ }^{13} \mathrm{http} / \mathrm{www}$ researchgate,net,Pertanggung jawaban pidana korporasi dalam pencemaran dan kerusakan lingkungan hidup,diakses tanggal 12 Nopember 2018.
} 


\section{Peraturan Perundang-Undangan}

Undang-Undang Nomor 4 Tahun 2009

Peraturan Pemerintah Nomor 23 Tahun 2010

Peraturan Pemerintah Nomor 13 Tahun 2011

\section{Internet}

http/www researchgate,net, Pertanggungjawaban pidana korporasi dalam pencemaran dan kerusakan lingkungan hidup, diakses tanggal 12 November 2018. 